\begin{tabular}{c} 
Volume and Issues Obtainable at Center for Sustainability Research and Consultancy \\
Sustainable Business and Society in Emerging Economies \\
ISSN: 2708-2504 (E): 2708-2172 \\
Volume 2: No 1, June 2020 \\
CSRᄃ \\
Journal homepage: www.publishing.globalcsrc.org/sbsee \\
\hline
\end{tabular}

\title{
Impact of Islamic Microfinance on Women borrower's Happiness: A Psychological and Economic Theoretical Perspective in Southern Punjab, Pakistan
}

\author{
${ }^{1}$ Sana Fayyaz, ${ }^{2}$ Fatima Khurram, ${ }^{3}$ Samar Fahd \\ ${ }^{1}$ Assistant Professor, Department of Economics, Govt. Sadiq College University of Bahawalpur, \\ Pakistan, sana.fayyaz@gscwu.edu.pk \\ ${ }^{2}$ Assistant Professor, Department of Applied Psychology, The Islamia University of Bahawalpur, \\ Pakistan, Fatima.khurram@iub.edu.pk \\ ${ }^{3}$ Lecturer, Department of Applied Psychology, The Islamia University of Bahawalpur, Pakistan, \\ samarphd14@nip.edu.pk
}

\begin{tabular}{|c|c|}
\hline ARTICLE DETAILS & ABSTRACT \\
\hline $\begin{array}{l}\text { History } \\
\text { Revised format: May } 2020 \\
\text { Available Online: June } 2020\end{array}$ & $\begin{array}{l}\text { The present research endeavors to see how Islamic microfinance } \\
\text { can be utilized to expand happiness in females and keep up } \\
\text { reasonable financial advancement in Southern Punjab, Pakistan. It }\end{array}$ \\
\hline $\begin{array}{l}\text { Keywords } \\
\text { microfinance,happiness, } \\
\text { women Bahawalpur, Pakistan, } \\
\text { Islamic, women } \\
\text { JEL Classification: } \\
\text { M20, M21 }\end{array}$ & $\begin{array}{l}\text { in expanding their happiness. It additionally set forth light on the } \\
\text { linkage between the monetary turn of events and satisfaction. The } \\
\text { review will be led in Bahawalpur the State of Southern Punjab, } \\
\text { Pakistan. It will likewise be viewed as that religion is definitely not } \\
\text { a blocking component to the usage of Islamic microfinance. It will } \\
\text { likewise accept that Islamic microfinance working together with the } \\
\text { privilege financial and fiscal arrangements structure, will contribute } \\
\text { emphatically to expand joy among ladies in Pakistan. }\end{array}$ \\
\hline
\end{tabular}

\section{OPEN $\bigcirc$ ACCESS}

(C) 2020 The authors, under a Creative Commons Attribution-

NonCommercial 4.0

Corresponding author's email address: sana.fayyaz@gscwu.edu.pk

Recommended citation: Fayyaz, S., Khurram, F., Fahad, S. (2020). Impact of Islamic Microfinance on Women borrower's Happiness: A Psychological and Economic Theoretical Perspective in Southern Punjab, Pakistan. Sustainable Business and Society in Emerging Economies, 2(1), 29-35

\section{Introduction}

Increasing happiness has been an unambiguous or absolute purpose for the group of the individuals of the nation as well as the world. In the life of every human, money has crucial importance. In this respect microfinance alludes to making little credits accessible to destitute individuals (particularly those generally rejected from money related administrations that is ladies) through projects planned explicitly to meet their specific needs and conditions (Khan, 2008). By a gauge, the effort of microfinance establishments is just 4 to 7 percent of the absolute potential market of 25 to 30 million borrowers (State Bank of Pakistan, 2006). While, the legislature of Pakistan has set an objective of arriving at 10 million microfinance clients continuously 2015 (Ibrar \& Saad, 2013). Predominantly, Non-Islamic microfinance is a loan providing services especially targeting for women and small scale businesses for those that do 
not have approach to banking and the other associated services. There are two primary instruments for the customers to get the financial services which are as: (1) banking for individuals and small scale or micro level businesses and (2) group- supported programs, wherever a few people meet up to pertain for loans and different services as a set of individuals. In a few areas, for example Southern Africa and Pakistan microfinance is used for the procurement of loans to poor individuals that is alike to the finance program persistent in conventional banking. Consequently, Islamic microfinance performs a dynamic role aimed at to the betterment of the circumstances of women in Pakistan as it is different from conventional loaning system and according to Islamic sharia, it gives them spiritual satisfaction as well (Christen, Rosenberg, \& Jayadeva, 2004).

Thus, Islamic Microfinance is a zone with an unfathomable potential to develop. It is assessed that $72 \%$ of the people living in pervasively. Muslims used conventional cash related things, however various surveys showed that in case they had choice they would use sharia-consistence budgetary things. One of Islamic targets is to help the most frail people that accounted in the microfinance vital. Today, the Islamic microfinance is moved in three countries: Indonesia, Bangladesh and Sudan. As demonstrated by Consultative Group to Assist the Poor (CGAP) (2016) study, 300,000 customers were concerned by the Islamic microfinance through 126 associations working in 14 countries and around 80,000 customers are associated with an arrangement of Indonesian cooperatives. Nevertheless, in Islamic countries, Islamic microfinance is up 'til now a little bit of microfinance. It as often as possible makes on account of government support as in Pakistan in 2007, where rules were made to propel improvement (Juliette, 2013).

Now a day, people switched from conventional microfinance to Islamic microfinance because of two out of numerous explanations behind the hole can be introduced here. One, that the quantity of individuals who are living in neediness is huge particularly in country regions and also, there are numerous potential merited customers who decrease the customary microfinance attributes and credits due to rebelliousness with Shariah of Islam. In addition, the traditional microfinance plans of activities dependent on intrigue (Riba) are precluded in Islam and subsequently, can't be utilized by and for the Muslims (Rahman, 2007). Likewise, there is a colossal appealing business sector for Islamic microfinance foundations in Pakistan. Islamic microfinance foundations are the associations that can make light of a job in bringing the hole and give chance to those potential customers who would prefer not to profit the administrations offered by customary microfinance organizations. In addition, Islamic microfinance is reasonable for Pakistan in light of the overwhelmingly Muslim populace as well as on account of the attention on the formation of a simply monetary framework (Kazim \& Haider, 2012).

Currently, the network of Islamic banking industry consisted of 22 Islamic banking institutions; 5 fullfledged Islamic banks (IBs) and 17 conventional banks having standalone Islamic banking branches (IBBs) by end December, 2018 (Sate bank of Pakistan, 2018). Thus, financing through Islamic Banking System, the role of microfinance has renewed into Islamic micro finance in Muslim nations. Therefore, this Islamic micro financing targeting the Islamic financial standards of equity which requires to lighten neediness and to empower the destitute individuals especially vulnerable women to make them capable by offering monetary types of assistance to lead a respectable and a tolerable life (Farooq \& Khan, 2014).

Commonly, a part of an ostensible Pakistani Islamic traditional society, woman has a financial dependency on man. Therefore, women have been marginalized often as a more vulnerable members of society. Mostly, it has been seen that females have to face the various boundaries imposed by the male dominant societies of underdeveloped and developing nations. At the community level without their male individuals they are not allowed to move outside the home and make contacts. Thus, the only way to get rid of this vulnerability is that when they are independent because of their own money they feel powerful psychologically. This feeling gives them self-confidence that leads them to be happy in their daily life decisions (Yasmeen \& Karim, 2014, Blumberg, 1984). 
Henceforth, in perspective of happiness it is enormously necessary to reduce the inequality of getting opportunities for women. This inequality is very common in the world, but are more present in under developing nations. On the whole women's function is as imperative as a men's position in giving power to the family and growth of the nation. She is eligible to the equal privileges and benefits as their partner nevertheless, the developing countries represent a unlike situation. There is an inborn difficulty that stops women from contributing in the decision making process and this will deny them from having happiness in their lives (Rehman, 2007). Thus, it is remembered that the above dialog robust that Islamic microfinance performs a significant role that leads to happiness of women in least developing nations. As they have finance they feel happiness in psychological perspective and economically they feel stable.

\section{Literature Review}

Happiness may be characterized as a positive enthusiastic state that is most broad and, subsequently, not limited to any particular circumstances or occasions (Kitayama, Markus and Matsumoto, 1995, 2000). Frey and Stutzer (2002) stated that happiness gives the different things and meanings to distinctive individuals. It is interested in everybody to characterize for themselves what Happiness is. They identified the concepts of happiness from the concept of subjective happiness. This subjective happiness (adapted from survey) will affect the objective happiness (scientific measures). The objective happiness will give feedback as cognition and memory to get indications of individuals' evaluations of happiness (Conceição \& Bandura, 2008). Thus, Budriute \& Makovska (2008) have illustrated their views in Latavia that the as main contributors of women happiness identified by marital status, employment status, household income and political trust.

In contrast women are at greater threat in terms of financial stability, occupation and living in male overwhelmed culture. There is no opportunity for them to grow in emerging countries. They have rising disparity in various societal and civilizing modes. It is due to the effect of many variables for example, absence of education, unemployment and marriages in young age and family hostility which have banned women from accomplishing better elevation. Furthermore the low condition of women is not only for the reason that of the norms of the society but it is engrained in the governmental and financial structure, which should be changed. Women put in the course of their effort in sustaining the family unit but it is not acknowledged as physical work. They are monetarily and communally reliant on male part of the family. Females do not get advantage from the standing as men in various respects (Rehman, 2007). Thus, to come out this alarming situation the Islamic microfinance is the best way to support the vulnerable women in the context of Islamic state and values.

On the same ground, Hassan and Saleem, (2017) revealed the some interesting facts of Islamic micro financing regarding poor women and noticed that the increase in women's income and assets played a very important role in enhancing women's economic independence (Economically) and sense of selfconfidence (Psychologically). It helped in breaking the cycle of poverty they live in and allowed them to have more control over their lives and economic decisions. Thus, the Islamic microfinance is way to provide a smooth financial services to facilitate the women.

Therefore, there is a great need of Islamic microfinance in Pakistan to increase the level of happiness among women especially in Pakistan. As there are very few work on the importance and applicability of Islamic microfinance in Pakistan. Hence, availability of Islamic microfinance plays an important role in happiness of women that will further leads to the betterment of family and society. Thus the present research will emphasis on the Impact of Islamic Microfinance on Women Borrowers happiness in Bahawalpur, Punjab, Pakistan. The current paper will make contribution to increase the happiness level of women.

\section{Problem Statement}

From the above critical assessment the problem statement mainly focuses on the issue of happiness of 
women which has been affected by lack of finance and critical socio-cultural conditions. Islamic microfinance significantly attributes to the economic development and progress of countries through involving themselves in some sort of economic activities with confidence and thus improving their quality of life which leads to happiness. Thus, Islamic microfinance plays an important role because, many people are far from the facilities given by old conventional microfinance system.

Meanwhile, majority of the Pakistan's population belong to remote regions. The province of Punjab especially, southern Punjab is particularly renowned as a patriarchal society. Females are the symbol of respect of males and not given their due human rights (Rehman, 2007). As per authority human rights of females are preoccupied with male rights (Maria, 2003). The people of Pakistan are extreme cohorts of conservative society. The parents of the girl conduct the social training for her as to obey and serve men in every situation, whether it is about household chores or critical matters of life like to choose the life partner and the decision of having number of children is also taken by the male member of the family (Shareef et al., 2012). However economic activities which have been highlighted in previous studies but not in the context of Islamic microfinance so it still require further exploration.

The social implications of women stature in such a conservative society asks for a contained access to resources whether they be of economic or non-economic nature (Maria, 2003). This deprivation of women is caused by lack of earnings. The low economic status of women asks for the economic liberation and acknowledgement of women as decision makers in economic and personal lives. This authorization may lead in the alleviation of the traditional exploitative customs, thereby relieving the next generation of these inordinate bounds exercised on women (Younas, 2007). Women in Pakistan are unable to start their own business because of lack of finance (Shabbir and Gregorio, 1996). As in the words of Khan (2007), the National Commission on the Status of Women (NCSW) survey- 2016 of home-based workers in Pakistan investigated that minority of women voted for home-based workers whereas majority of women voted to have loans to start their own business. There is a need of women authorization and liberation in order to empower them in their personal and economic capacities. Thus, there is essential to study the effect of economic activity on women borrowers' happiness (Laila, 2006).

In this expression the world happiness report (2019) that out of 155 countries, rather the rank of Pakistan in happiness is 67 at the world level, but the downward changes in the happiness level occurs from (2017-2018) is in negative (-0.312), which shows that happiness of the Pakistan is decreasing gradually due to the poor quality of life (World Happiness Report, 2019).

Table 1.1

Happiness and Rate of Change in Happiness in South Asian Countries 2019

\begin{tabular}{cccccccc}
\hline Countries & Bhutan & Pakistan & Bangladesh & India & Sri Lanka & Nepal & Afghanistan \\
\hline $\begin{array}{c}\text { Rank of } \\
\text { Happiness }\end{array}$ & 95 & 67 & 125 & 140 & 130 & 100 & 154 \\
$\begin{array}{c}\text { Happiness } \\
\text { Level }\end{array}$ & 5.08 & 5.65 & 4.45 & 4.02 & 4.36 & 4.91 & 3.20 \\
$\begin{array}{c}\text { Rate of } \\
\text { Change in }\end{array}$ & n.a1 & 0.703 & -0.195 & -1.137 & -0.030 & 0.328 & -0.520 \\
Happiness & & & & & & & \\
\hline
\end{tabular}

Source: World Happiness Report, 2019

Even the rate of change in happiness of Bangladesh, India, Sri Lanka and Afghanistan are also decreasing gradually $(-0.195,-1.137,-0.030,-0.520)$ respectively, except Pakistan and Nepal whose happiness level is increasing $67(+0.703)$ and $100(0.328)$ in 2019. While in 2017- 2018 both are on $81(-$ 0.312 ) and 121 (-0.143) correspondingly, which shows the living standard is getting better day by day. Henceforth in the greater part of the emerging nations, micro credit especially encourages the underprivileged individuals to begin little business with a specific end goal to build their income, and as

\footnotetext{
${ }^{1}$ n.a; not available.
} 
an outcome to accomplish a superior expectation for everyday comforts for themselves and their families (Jamal, 2008).

Islamic Microfinance is a tool to increase living standard of people in developing countries by increasing their income levels and better sustenance for family members. Women are a key factor in development of society and country. Most of the research is done on the women in the Western countries. Pakistani culture and societal norms are bit different as compared to other societies in the west. Steady quality of life may generate a different impact on lives of women in a Pakistani society as compared to other countries. It is wildly believed that participation of women in labor force improve the monetary independence of women which indicates towards happiness, satisfaction in life and in improving quality of life. Hence, there is great need to study on women in Pakistan in the context of Islamic microfinance.

Islamic Microfinance is a new field in Pakistan as it emerges in Pakistan in 2007. There are few researches in the context of women with respect to Islamic microfinance. In Pakistan, this takes latest scrutiny prospect that will try to inaugurate a dynamic part of Islamic microfinance with happiness in women. It is highly essential to realize the effect of Islamic microfinance with happiness of women and supportive factors. Moreover, the studies have been overseen in distinctive view. Thus, the most offended side of the society are women. Hence this is a important prerequisite to give attention on the latest alarming problems that expands the meaning of happiness amongst females.

\section{Methodology}

The most suitable research design for this study will be Quantitative. The methodology will be used mostly by regression analysis and doing correlation of cross-sectional data. A few other inquiries are involved in the interviews to reflect the details regarding the happiness of the women via Islamic microfinance. Also, interviews are conducted with the field officers of the Islamic microfinance program managed by Islamic banks providing microfinance loans.

\subsection{Design of the study}

For this study, the most appropriate research design will be quantitative. Therefore, women borrowers will be the principle objective of this research to investigate the impact of Islamic microfinance. Moreover, to fulfil the analyst needs the correlational methodology will be appropriate to identify the crucial components that relates to the dependent variable. A representation of population will be taken as a significant conclusion. It will be depicted around a fact in a specified time that is representative of the total population. Further, to collect the data a survey questionnaire will be used.

\subsection{Participants}

A sample of 164 women from the population will be selected as a participant of the study. The current research expects to investigate the impact of Islamic microfinance on Women's borrower's happiness. The ages of females from 18 to 65 years will be selected as a sample of the present study from the division Bahawalpur, Southern Punjab, Pakistan. Therefore, $\mathrm{G}^{*}$ power technique will be used to collect the data by using non-random sampling technique. Convenience Sampling will be used for sampling procedure.

\subsection{Data Analysis}

The Partial Least Square software will be used for the Structural equation modeling for the analysis of data collected by the questionnaire survey. For this purpose, descriptive statistics will use for each measurement of the research.

\section{Conclusions}

Wrapping up, the current research is estimated to endorse considerably on women borrower's happiness in under developing country like Pakistan. The present research will be a great support in literature review. The previous researches focused on only the relationship of the variables. Nevertheless, the 
current study will put emphases on the remaining important factors that are under studied till now. Specifically, this research will be a revolutionary endeavor to broaden the literature. In economic research this study will have many societal and concrete effects.

Accordingly, in emerging good community the current research focuses the key factors that having an impact on the Pakistani society. These dynamics are acknowledged as an important factor which is ignored at policy level in Pakistan. The key points in the present research is Islamic microfinance will improve the happiness of women because it also fulfills their spiritual satisfaction. Women may have more comfortable when there are no economic restraints. The vital purpose of life of a woman is being at peace which may indicate towards respectable happiness in life.

\section{References}

Bandyopadhyay, T., \& Shankar, S. (2014). The impact of the 2010 Andhra Pradesh crisis on the operational efficiency of Indian microfinance institutions. In Microfinance Institutions (pp. 119138). Palgrave Macmillan UK.

Blumberg, R. L. (1984). A general theory of gender stratification. Sociological theory, 23-101.

Budriute, L. \& Makovska, M. (2008). Beyond GDP: What makes people in Latvia and Lithuania happy? Research Paper.

Christen, R. P., Rosenberg, R., and Jayadeva, V. (2004) Financial institutions with a double bottom line: implications for the future of microfinance. CGAP Occasional Paper, July, pp. 23.

Conceição, P., \& Bandura, R. (2008). Measuring subjective wellbeing: A summary review of the literature. United nations development programme (UNDP) development studies, working paper.

Farooq, M., \& Khan, Z. (2014). The social and financial performance of conventional and Islamic microfinance institutions in Pakistan. Al-Idah, 28, 17-35.

Frey, B. \& Stutzer, A. (2002). Happiness and economics. Princeton University press: United Kingdom.

Frey, B. S. \& Stutzer A. (2002). The Economics of happiness. World economics. Vol. 3(1).

Hassan, A., \& Saleem, S. (2017). An Islamic microfinance business model in Bangladesh: Its role in alleviation of poverty and socio-economic well-being of women. Humanomics, 33(1), 15-37.

Ibrar, Saad (2013) Performance of Micro Finance Sector in Pakistan, Daily the Nation, 5th June, 2013.

Imran Sharif Chaudhry, Farhana Nosheen, Muhammad Idrees Lodhi (2012) Women Empowerment in Pakistan with Special Reference to Islamic Viewpoint: An Empirical Study, Pakistan Journal of Social Sciences (PJSS)Vol. 32, No. 1, pp.171-183.

Jamal, H. (2008). Exploring the impact of Microfinance in Pakistan. Research Report volume No.77 .June pp16-18.

Juliette, (2013). What is Islamic Microfinance? Retrieved on 30th April, 2016 retrieved from http://www.microworld.org

Kazim, S. S. and Haider, S. E. (2012) Islamic Microfinance Models and their viability in Pakistan. MicroNote No. 15, Pakistan Microfinance Network.

Khan, A., A. (2008). "Islamic Microfinance Theory, Policy and Practice", Islamic Relief Worldwide, Birmingham, United Kingdom, February.

Khan, M. A., \& Rahaman, M. A. (2007). Impact of microfinance on living standards, empowerment and poverty alleviation of poor people: a case study on microfinance in the Chittagong District of Bangladesh. Master's Thesis, Umea University, Sweden.

Kitayama, S., H.R. Markus and H. Matsumoto: 1995, 'Culture, self, and emotion: A cultural perspective on 'self-conscious' emotions', in J.P. Tangney and K.W. Fischer (eds), Self-conscious Emotions: The Psychology of Shame, Guilt, Embarrassment, and Pride (Guilford Press, New York), pp. 439-464.

Kitayama, S., H.R. Markus and M. Kurokawa: 2000, 'Culture, emotion, and well-being: Good feelings in Japan and the United States', Cognition and Emotion 14, pp. 93-124.

Laila, U. (2006). Impact of socio-cultural factors on personality development of adolescent. Unpublished Ph.D.Thesis, Department of Rural Sociology, University of Agriculture, Faisalabad. 
Maria, S. Gobbi, D. (2003).Nepal \& Pakistan Micro finance and microenterprise development: their contribution to the economic empowerment of the women. PP 6, 20-25 68.

Micro Credit Improve Well-being of Borrowers in the Punjab (Pakistan)? Pakistan Economic and Social Review, 31-47.

Pakistan Human Rights Commission Report, 2012; retrieved on 3rd march 2016, Retrieved from www.state.gov/documents.

Rahman, A. R. A. (2007) Islamic Microfinance: A Missing Component in Islamic Banking, Kyoto Bulletin of Islamic Area Studies, 1-2, pp. 38- 53.

Rehman, W. (2007). Micro finance barriers to the microfinance out reach for women in Pakistan PP.7, 9, 22, 15, Department of Economics Uppsala.

SBP (2006) Financial Stability Review, State Bank of Pakistan, Islamabad

Serrano, L. D. \& Pose, A. R. (2011). Decentralization, happiness and the perception of institutions. Working paper.

Shabbir, A. and Di Gregorio, S. (1996), "An examination of the relationship between women's personal goals and structural factors influencing their decision to start a business: the case of Pakistan", Journal of Business Venturing, Vol. 11 No. 6, p. 507.

Shah, Nasra. M. (1986) Female Employment: Trends, Structure, Utilisation and Constraints. In Nasra M. Shah (ed.) Pakistani Women: A Socio-economic and Demographic Profile. Pakistan Institute of Development Economics, Islamabad/East-West Population Institute, Honolulu, Hawaii.

Sharma, P. P. (2014). Microfinance: The Catalyst of GNH Index. Parikalpana: KIIT Journal of Management, 10(2), 73.

World Happiness Report (2017); John F. Helliwell, Richard Layard and Jeffrey D. Sachs. Retrieved on (2017), Retrieved from http://www.theglobeandmail.com .

Yasmeen, K., \& Karim, M. Z. A. (2014). Impact of interaction term between education and loan size on women's decision making. Journal of Entrepreneurship and Business Innovation, 1(1), 123-141.

Yunus, M. (2007). Akhter, W., Akhtar, N., \& Jaffri, S. K. A. (2009). Islamic micro-finance and poverty alleviation: a case of Pakistan. Proceeding of the 2 nd CBRC, Lahore. 